CIVICS EDUCATION AND SOCIAL SCIENSE JOURNAL(CESSJ)

Volume 2 Nomor 2 Edisi Bulan Desember 2020

\title{
ANALISIS PENYELENGGARAAN PEMILIHAN KEPALA DESA DI DESA GEBYOG KECAMATAN MOJOGEDANG KABUPATEN KARANGANYAR TAHUN 2020
}

\author{
Penulis \\ Bunadi \\ GURU SMK Muhammadiyah 1 Karanganyar \\ Email: bunadi_2020@gmail.com
}

\begin{abstract}
ABSTRAK
Penelitian ini bertujuan: 1) mendeskripsikan penyelenggaraan pemilihan kepala desa di Desa Gebyog tahun 2020; 2) mengetahui faktor yang menghambatdan mendukung dalam penyelenggaraan Pemilihan Kepala Desa di Desa Gebyogtahun 2020.

Penelitian ini mengunakan metode kualitatif dengan jenis penelitiandeskriptif. Metode penelitian kualitatif, yaitu suatu analisis berdasarkan data yangdiperoleh melalui wawancara, observasi dan dokumentasi. Dalam penelitian ini,data yang dikumpulkan terdiri dari: Data primer yang merupakan sumber datautama, diperoleh dari hasil wawancara kepada Panitia Pemilihan Kepala Desa,dan dokumentasi pelaksanaan Pemilihan kepala desa. Sedangkan data sekunderdiperoleh dari literatur atau buku-buku yang berkaitan dengan pemilihan kepaladesa. Setelah data diperoleh, kemudian dianalisa dengan menggunakan metodedeskriptif analisis yaitu penggambaran proses pelaksanaan pemilihan kepala desayang terjadi di lapangan.

Pelaksanaan pemilihan kepala desa di Desa Gebyog Tahun 2020 dimulai dari tahapan persiapan, pencalonan hingga pemungutan suara dapat penulissimpulkan bahwa telah berjalan sesuai dengan prosedur. Faktor penghambatpelaksanaan pemilihan kepala desa yaitu tingkat pendidikan, dan kurangnyapemahaman terhadap aturan pemilihan kepala desa yang berlaku. Faktorpendukung pelaksanaan pemilihan kepala desa Gebyog Tahun 2020 yaituPartisipasi masyarakat dalam kegiatan kampanye calon kepala desa dan tingginyatingkat partisipasi masyarakat dalam pemungutan suara pemilihan kepala desa.
\end{abstract}

Kata kunci : penyelenggaraan, pemilihan kepala desa

JORNAL PROGDI PPKn, FKIP UNIVET BANTARA SUKOHARJO BEKERJA SAMA DENGANASSOSIASI PROFESI PENDIDIKAN PANCASILA DAN KEWARGANEGARAAN (AP3KNI) JAWA TENGAH 


\title{
ANALYSIS OF VILLAGE HEAD ELECTION IN GEBYOG VILLAGE, KECAMATAN MOJOGEDANG KARANGANYAR DISTRICT IN 2020
}

\author{
Author \\ Bunadi \\ TEACHER OF SMK Muhammadiyah 1 Karanganyar \\ Email: bunadi2020@gmail.com
}

\begin{abstract}
This study aims: 1) to describe the implementation of village head elections in Gebyog Village in 2020 ; 2) knowing the factors that hinder and support the implementation of the Village Head Election in Gebyog Village in 2020.

This research uses qualitative methods with descriptive research type. Qualitative research methods, namely an analysis based on data obtained through interviews, observation and documentation. In this study, the data collected consisted of: Primary data which is the main data source, obtained from the results of interviews with the Village Head Election Committee, and documentation of the implementation of village head elections. Meanwhile, secondary data were obtained from literature or books related to the election of the head of the village. After the data is obtained, then it is analyzed using descriptive analysis methods, namely the depiction of the process of implementing the village head election that occurs in the field. The implementation of the village head election in Gebyog Village in 2020 starts from the preparation stage, nomination to voting, the authors can conclude that it has gone according to procedure. Inhibiting factors for the implementation of village head elections are the level of education, and a lack of understanding of the applicable village head election rules. Supporting factors for the implementation of the 2020 Gebyog village head election, namely community participation in village head candidate campaign activities and the high level of community participation in voting for village head elections.
\end{abstract}

Keywords: implementation, village head election

JORNAL PROGDI PPKn, FKIP UNIVET BANTARA SUKOHARJO BEKERJA SAMA DENGANASSOSIASI PROFESI PENDIDIKAN PANCASILA DAN KEWARGANEGARAAN (AP3KNI) JAWA TENGAH 


\section{PENDAHULUAN}

Menurut UU No. 22 Tahun 1999 Desa adalah kesatuan masyarakat hukum yang memiliki kewenangan untuk mengatur dan mengurus kepentingan masyarakat setempat berdasarkan asal-usul dan adat istiadat setempat yang diakui dalam sistem pemerintahan nasional dan berada di daerah kabupaten. Desa juga memiliki kekuasaan untuk menyelenggarakan pemerintahannya sendiri dalam ikatan Negara Kesatuan Republik Indonesia (NKRI). Secara historis, desa merupakan cikal bakal terbentuknya masyarakat politik dan pemerintahan di Indonesia jauh sebelum negara bangsa ini terbentuk, struktur sosial sejenis desa, masyarakat adat dan lain sebagainya telah menjadi institusi sosial yang mempunyai posisi yang sangat penting. Penyelenggaraan pemerintah desa merupakan sub sistem dari sistem penyelenggaraan pemerintahan, sehingga desa memiliki kewenangan untuk mengatur dan mengurus kepentingan masyarakatnya.

Pemerintah desa terdiri atas kepala desa dan perangkat desa sebagai unsur penyelenggara pemerintahan desa. Pemerintah desa dipimpin oleh seorang kepala desa yang memiliki peran membina kehidupan masyarakat desa, memelihara ketentraman dan ketertiban masyarakat desa, mendamaikan perselisihan masyarakat di desa dan membina perekonomian desa guna meningkatkan kesejahteraan dan kemajuan desa.

Hal ini menjadi penanda adanya perbedaan mendasar antara corak pemerintahan desa dan kelurahan. Menurut ketentuan, lurah merupakan bagian dari perangkat pemerintah kabupaten atau kota yang ditempatkan di kelurahan. Dalam menentukan dan memilih pemimpinnya, warga kelurahan tidak memiliki hak seperti pada warga masyarakat desa, yang memilih pemimpin yang disebut kepala desa, melalui sistem pemilihan kepala desa, namun berdasarkan penunjukkan atau penugasan dari bupati/walikota. Berlainan dengan desa, melalui pemilihan kepala desa rakya desa memilih dan menentukan jabatan kepala desa secara langsung, melalui ajang yang disebut Pilkades.

Pemilihan kepala desa sebagai pesta demokrasi. Sebelumnya sudah berlangsung sejak zaman dahulu, dengan harapan terbentuknya sosok pemimpin yang mampu mengayomi masyarakat, menjadi panutan masyarakat, dan mampu membawa kemajuan bagi masyarakat. Dalam Pelaksanaan Pemilihan kepala desa, ada tiga hal penting dalam prosesnya yaitu aspek kompetisi antar konstestan, partisipasi, dan kebebasan (liberalisasi). Aspek kompetisi berkaitan dengan orangorang yang mencalonkan diri sebagai kepala desa dan cara-cara yang dipakai untuk menjadikan mereka ini sebagai calon kepala desa. Aspek partisipasi berkaitan dengan pemahaman masyarakat terhadap pemilihan kepala desa, cara mereka merumuskan tipe kepemimpinan kepala desa dan model mereka membangun kesepakatan politik dengan para calon kepala desa.

Sebagaimana Undang-undang Nomor 6 Tahun 2014 Tentang Desa sebagai dasar atau rujukan dalam Proses Pemilihan Kepala Desa seperti yang dikemukakan diatas, maka di Desa Gebyog Kecamatan Mojogedang Kabupaten Karanganyar dilaksanakan Pemilihan Kepala Desa juga pada tahun 2020. 
Pemilihan Kepala Desa ini sudah berlangsung setiap 5 tahun sekali. Namun berdasarkan Undang-Undang No.6 Tahun 2014 Tentang desa jabatan Kepala Desa menjadi 6 tahun. Pemilihan Kepala Desa diikuti oleh semua penduduk yang memenuhi persyaratan baik secara administratif maupun non administratif, baik tunggal maupun lebih dari satu orang calon. Calon Kepala Desa bersaing secara ketat dan biasanya antara calon yang satu dengan calon yang lainnya akan berusaha dengan berbagai cara untuk mendapatkan dukungan dari warga masyarakat.

Pemilihan Desa Gebyog sebagai desa tempat penelitian bukan hanya semata-mata merupakan domisili penulis, tetapi banyak aspek yang mendukung penelitian tentang pemilihan kepala desa ini dilaksanakan di Desa Gebyog.

Berdasarkan latar belakang tersebut di atas maka penulis tertarik untuk pelakukan penelitian skripsi dengan judul "Analisis Penyelenggaraan Pemilihan Kepala Desa Di Desa Gebyog Kecamatan Mojogedang Kabupaten Karanganyar Tahun $2020 "$.

Berdasarkan paparan pendahuluan di atas, maka dapat dirumuskan beberapa permasalahan yang menarik untuk dikaji dan dianalisis, antara lain: Bagaimana pelaksanaan pemilihan kepala desa di Desa Gebyog Kecamatan Mojogedang Kabupaten Karanganyar Tahun 2020. Faktor-faktor apa saja yang menghambat dan mendukung penyelenggaraan pemilihan kepala desa di Desa Gebyog Kecamatan Mojogedang Kabupaten Karanganyar Tahun 2020.

\section{KAJIAN TEORI}

\section{Negara Hukum}

Negara hukum dalam pengertian state based on rule of law, rechsstaat yakni negara hukum yang demokratis. Negara hukum berdasar hukum. Penegasan bahwa Indonesia sebagai negara hukum bisa dilihat pada pasal 1 ayat 3 UUD RI 1945 yang berbunyi "Negara Indonesia adalah negara hukum". Negara hukum dimaksud adalah negara yang menegakkan supremasi hukum untuk menegakkan kebenaran dan keadilan dan tidak ada kekuasaan yang tidak dipertanggungjawabkan.

Berdasarkan uraian di atas yang dimaksud negara hukum ialah negara yang berdiri di atas hukum yang menjamin keadilan kepada warganya. Keadilan merupakan syarat bagi terciptanya kebahagiaan hidup untuk warga negaranya, dan sebagai dasar dari pada keadilan itu perlu diajarkan rasa susila kepada setiap manusia agar menjadi warga negara yang baik. Demikian pula peraturan hukum yang sebenarnya hanya ada jika peraturan hukum itu mencerminkan keadilan bagi pergaulan hidup antar warga negaranya.

Pengertian negara hukum secara sederhana adalah negara yang penyelenggaraan kekuasaan pemerintahannya didasarkan atas hukum. Dalam negara hukum, kekuasaan menjalankan pemerintahan berdasarkan kedaulatan 
hukum (supremasi hukum) dan bertujuan untuk menjalankan ketertiban hukum (Mustafa Kamal Pasha, dalam Dwi Winarno, 2006).

Dengan demikian dalam negara hukum, kekuasaan negara berdasar atas hukum, bukan kekuasaan belaka serta pemerintahan negara berdasar pada konstitusi yang berpaham konstitusionalisme, tanpa hal tersebut sulit disebut sebagai negara hukum. Supremasi hukum harus mencakup tiga ide dasar hukum, yakni keadilan, kemanfaatan, dan kepastian. Oleh karena itu di negara hukum, hukum harus tidak boleh mengabaikan "rasa keadilan masyarakat".

Menurut Juniarso Ridwan (2009) menyatakan bahwa hubungan antara masyarakat dengan hukum merupakan satu kesatuan yang tidak dapat dipisahkan. Ini sesuai dengan ungkapan ubi societes ibi ius (dimana ada masyarakat disitu ada hukum). Dapat ditegaskan bahwa hukum memilik fungsi untuk mengatur kehidupan masyarakat dalam melanjutkan aktivitasnya, sehingga melalui pengaturan itu bisa terwujudkan suatu masyarakat yang sejahtera, sesuai dengan yang diamanatkan dari tujuan negara Indonesia yang tercantum dalam pembukaan UUD 1945.

Frans Magnis Suseno (1997) mengemukakan adanya 5 (lima) ciri negara hukum sebagai salah satu ciri hakiki negara demokrasi. Kelima ciri negara hukum tersebut adalah sebagai berikut.

1. Fungsi kenegaraan dijalankan oleh lembaga yang bersangkutan sesuai dengan ketetapan sebuah undang-undang dasar.

2. Undang-undang dasar menjamin hak asasi manusia yang paling penting. Karena tanpa jaminan tersebut, hukum akan menjadi sarana penindasan. Jaminan hak asasi manusia memastikan bahwa pemerintah tidak dapat menyalahgunakan hukum untuk tindakan yang tidak adil atau tercela

3. Badan-badan negara menjalankan kekuasaan masing-masing selalu dan hanya taat pada dasar hukum yang berlaku.

4. Terhadap tindakan badan negara, masyarakat dapat mengadu ke pengadilan dan putusan pengadilan dilaksanakan oleh badan negara.

5. Badan kehakiman bebas dan tidak memihak.

Dalam ciri ini terkandung ketentuan bahwa pengadilan sebagai lembaga peradilan dan badan kehakiman harus benar-benar independen dalam membuat putusan hukum, tidak dipengaruhi oleh kekuasaan lain terutama kekuasaan eksekutif. Dengan wewenang sebagai lembaga yang mandiri terbebas dari kekuasaan lain, diharapkan negara dapat menegakkan kebenaran dan keadilan. Legalitas dalam arti hukum dalam segala bentuknya Bahwa segala tindakan penyelenggara negara maupun warga negara dibenarkan oleh kaidah hukum yang berlaku serta dapat dipertanggungjawabkan secara hukum. 


\section{Demokrasi}

Dalam sejarahnya, demokrasi sering bersanding dengan kebebasan (freedom). Namun demikian, demokrasi dan kebebasan tidaklah identik. Demokrasi merupakan sebuah kumpulan ide prinsip tentang kebebasan, bahkan juga mengandung sejumlah praktik dan prosedur menggapai kebebasan yang terbentuk melalui perjalanan sejarah panjang dan berliku. Secara singkat, demokrasi merupakan bentuk institusionalisasi dari kebebasan (Institutionnalazationof freedom). Berdasarkan pada argumen ini, untuk melihat apakah suatu pemerintah dapat dikatakan demokratis atau tidak terletak pada sejauhmana pemerintah tersebut berjalan pada prinsip konstitusi, hak asasi manusia, dan persamaan warga negara di hadapan hukum.

Sejalan dengan perkembangannya, demokrasi mengalami pemaknaan yang berkembang di kalangan para ahli tentang demokrasi. Menurut Joseph A. Schmitter, demokrasi adalah suatu perencanaan institusional untuk mencapai keputusan politik dimana setiap individu memperoleh kekuasaan untuk memutuskan cara perjuangan kompetitif atas suara rakyat. Adapun menurut Sidney Hook, demokrasi adalah bentuk pemerintahan dimana keputusan-keputusannya yang penting secara langsung atau tidak langsung didasarkan pada kesepakatan mayoritas yang diberikan secara bebas dari warga negara dewasa.

Pada dasarnya banyak negara yang memilih sistem demokrasi,karena demokrasi memiliki nilai (values) yang menjamin hak dan kewajiban warga negaranya yang lebih humanistik. Demokrasi tumbuh berkembang subur di dalam masyarakat madani, masyarakat yang mencintai kedamaian, ketenangan, dan sejahtera. Demokrasi menjanjikan kehidupan politik yang menjamin ketersediaan pemenuhan hak, sekurang-kurangnya menyampaikan pendapat yang ada di dalam pikiran seseorang, dengan hal ini, membuat manusia berada dalam tempat yang layak sebagai seorang manusia yang seutuhnya.

Demokrasi adalah bentuk atau mekanisme sistem pemerintahan suatu negara sebagai upaya mewujudkan kedaulatan rakyat (kekuasaan warganegara) atas negara untuk dijalankan oleh pemerintah negara tersebut. Salah satu pilar demokrasi adalah prinsip trias politica yang membagi ketiga kekuasaan politik negara (eksekutif, yudikatif dan legislatif) untuk diwujudkan dalam tiga jenis lembaga negara yang saling lepas (independen) dan beradabersama. Demokrasi menguatkan struktur-massa, pembangunan ekonomi, budaya politik, interaksi elite poltik. Dan pendalaman demokrasi membuat struktur-struktur formal demokrasi menjadi lebih liberal, akuntabel, representatif, dan aksesibel.

Henry B. Mayo telah merinci nilai-nilai yang terkandung dalam sistem demokrasi, yaitu;

1. Menyelesaikan perselisihan dengan damai dan secara lembaga (institutionalized peacefull settlement of conflict). 
2. Menjamin terselenggaranya perubahan secara damai dalam suatu masyarakat yang sedang berubah (peaceful change in a changing society).

3. Menyelenggarakan pergantian pimpinan secara teratur (orderly succession of rulers).

4. Membatasi pemakaian kekerasan sampai minimum (minimum of coercion).

5. Mengakui serta menganggap wajar adanya keanekaragaman (diversity) dalam masyarakat yang tercermin dalam keanekaragaman pendapat, kepentingan, serta tingkah laku.

6. Menjamin tegaknya keadilan

\section{Desa}

Secara etimologi kata desa berasal dari bahasa Sansekerta,deca yang berarti tanah air, tanah asal, atau tanah kelahiran. Dari perspektif geografis, desa atau village diartikan sebagai a groups of houses or shops in a country area, smaller than a town". Desa adalah kesatuan masyarakat hukum yang memiliki kewenangan untuk mengurus rumah tangganya sendiri berdasarkan hak asal-usul dan adat istiadat yang diakui dalam pemerintah nasional dan berada di Daerah Kabupaten. Menurut Widjaya (2003) menyebutkan pengertian desa adalah sebagai berikut :

"Desa adalah kesatuan masyarakat hukum yang mempunyai susunan asli berdasarkan hak asal-usul yang bersifat istimewa. Landasan pemikiran dalam mengenai pemerintah desa adalah keanekaragaman, partisipasi, otonomi asli, demokratisasi dan pemberdayaan masyarakat"

Pengertian desa menurut UU. No. 22 Tahun 1999 adalah kesatuan masyarakat hukum yang memiliki kewenangan untuk mengatur dan mengurus kepentingan masyarakat setempat berdasarkan asal usul dan adat istiadat setempat yang diakui dalam sistem pemerintahan Nasional dan berada di daerah Kabupaten. Menurut Undang-undang Republik Indonesia Nomor 6 tahun 2014 tentang desa menyebutkan bahwa desa adalah sebagai berikut :

Desa adalah desa dan desa adatatau yang disebut dengan nama lain, selanjutnya disebut desa adalah kesatuan masyarakat hukum yang memiliki batas wilayah yang berwenang untuk mengatur dan mengurus urusan pemeritah, kepentingan masyarakat setempat berdasarkan prakarsa masyarakat, hak asal usul dan/atau hak tradisional yang diakui dan dihormati dalam sistem pemerintahan Negara Kesatuan Republik Indonesia

Desa merupakan selfcommunity yaitu komunitas yang mengatur dirinya sendiri. Dengan pemahaman bahwa desa memiliki kewenangan untuk mengurus dan mengatur kepentaingan masyarakatnya sesuai dengan kondisi dan sosial budaya setempat, maka posisi desa yang memiliki otonomi asli sangat strategi sehingga memerlukan perhatian yang seimbang terhadap 
penyelenggaraan otonomi daerah. Karena dengan otonomi dessa yang kuat akan mempengaruhi secara signifikat perwujudan otonomi daerah. Menurut Undang-undang Republik Indonesia tahun 2014 nomor 6 tahun 2014 tentang Desa menyebutkan bahwa desa berkedudukan di wilayah kabupaten/kota. Desa terdiri atas desa dan desa adat.

\section{Pemerintahan Desa}

Menurut Undang-undang Republik Indonesia Nomor 6 Tahun 2014 tentang Desa menyebutkan bahwa pemerintahan desa adalah sebagai berikut: "Pemerintah desa adalah penyelenggaraan urusan pemerintahan dan kepentingan masyarakat setempat dalam sistem pemerintahan Negara Kesatuan Republik Indonesia". Menurut Peraturan Menteri Dalam Negeri Republik Indonesia Nomor 84 Tahun 2015 tentang Susunan Organisasi dan Tata Kerja Pemerintah Desa menyebutkan bahwa tugas dan fungsi pemerintah desa yaitu sebagai berikut:

\section{a. Kepala Desa}

Kepala Desa berkedudukan sebagai Kepala Pemerintah Desa yang memimpin penyelenggaraan Pemerintahan Desa.Kepala Desa memiliki tugas dan fungsi-fungsi sebagai berikut:

1) Menyelenggarakan Pemerintahan Desa, seperti tata praja Pemerintahan, penetapan peraturan di desa, pembinaan masalah pertanahan, pembinaan ketentraman dan ketertiban, melakukan upaya perlindungan masyarakat, administrasi kependudukan, dan penataan dan pengelolaan wilayah.

2) Melaksanakan pembangunan, seperti pembangunan sarana prasarana perdesaan, dan pembangunan bidang pendidikan, kesehatan.

3) Pembinaan kemasyarakatan, seperti pelaksanaan hak dan kewajiban masyarakat, partisipasi masyarakat, sosial budaya masyarakat, keagamaan, dan ketenagakerjaan.

4) Pemberdayaan masyarakat, seperti tugas sosialisasi dan motivasi masyarakat di bidang budaya, ekonomi, politik, lingkungan hidup, pemberdayaan keluarga, pemuda, olahraga, dan karang taruna.

5) Menjaga hubungan kemitraan dengan lembaga masyarakat dan lembaga lainnya.

\section{b. Sekretaris Desa}

Sekretaris Desa berkedudukan sebagai unsur pimpinan Sekretariat Desa. Sekretaris Desa bertugas membantu Kepala Desa dalam bidang administrasi pemerintahan.Sekretaris Desa mempunyai fungsi:

1) Melaksanakan urusan ketatausahaan seperti tata naskah, administrasi surat menyurat, arsip, dan ekspedisi.

2) Melaksanakan urusan umum seperti penataan administrasi perangkat desa, penyediaan prasarana perangkat desa dan kantor, penyiapan 
rapat, pengadministrasian aset, inventarisasi, perjalanan dinas, dan pelayanan umum.

3) Melaksanakan urusan keuangan seperti pengurusan administrasi keuangan, administrasi sumber-sumber pendapatan dan pengeluaran, verifikasi administrasi keuangan, dan administrasi penghasilan kepala desa, perangkat desa, BPD, dan lembaga pemerintahan desa lainnya.

4) Melaksanakan urusan perencanaan seperti menyusun rencana anggaran pendapatan dan belanja desa, menginventarisir data-data dalam rangka pembangunan, melakukan monitoring dan evaluasi program, serta penyusunan laporan.

\section{c. Kepala Urusan}

Kepala Urusan berkedudukan sebagai unsur staf sekretariat.Kepala Urusan bertugas membantu Sekretaris Desa dalam urusan pelayanan administrasi pendukung pelaksanaan tugas-tugas pemerintahan.Kepala Urusan mempunyai fungsi:

1) Kepala urusan tata usaha dan umum memiliki fungsi seperti melaksanakan urusan ketatausahaan seperti tata naskah, administrasi surat menyurat, arsip, dan ekspedisi, dan penataan administrasi perangkat desa, penyediaan prasarana perangkat desa dan kantor, penyiapan rapat, pengadministrasian aset, inventarisasi, perjalanan dinas, dan pelayanan umum.

2) Kepala urusan keuangan memiliki fungsi seperti melaksanakan urusan keuangan seperti pengurusan administrasi keuangan, administrasi sumber-sumber pendapatan dan pengeluaran, verifikasi administrasi keuangan, dan administrasi penghasilan Kepala Desa, Perangkat Desa, BPD, dan lembaga pemerintahan desa lainnya.

3) Kepala urusan perencanaan memiliki fungsi mengkoordinasikan urusan perencanaan seperti menyusun rencana anggaran pendapatan dan belanja desa, menginventarisir data-data dalam rangka pembangunan, melakukan monitoring dan evaluasi program, serta penyusunan laporan.

\section{d. Kepala Seksi berkedudukan sebagai unsur pelaksana teknis.}

Kepala Seksi bertugas membantu Kepala Desa sebagai pelaksana tugas operasional.Untuk melaksanakan tugas Kepala Seksi mempunyai fungsi:

1) Kepala Seksi Pemerintahan mempunyai fungsi melaksanakan manajemen tata praja Pemerintahan, menyusun rancangan regulasi desa, pembinaan masalah pertanahan, pembinaan ketenteraman dan ketrtiban, pelaksanaan upaya perlindungan masyarakat, kependudukan, penataan dan pengelolaan wilayah, serta pendataan dan pengelolaan Profil Desa. 
2) Kepala Seksi Kesejahteraan mempunyai fungsi melaksanakan pembangunan sarana prasarana perdesaan, pembangunan bidang pendidikan, kesehatan, dan tugas sosialisasi serta motivasi masyarakat di bidang budaya, ekonomi, politik, lingkungan hidup, pemberdayaan keluarga, pemuda, olahraga, dan karang taruna.

3) Kepala Seksi Pelayanan memiliki fungsi melaksanakan penyuluhan dan motivasi terhadap pelaksanaan hak dan kewajiban masyarakat, meningkatkan upaya partisipasi masyarakat, pelestarian nilai sosial budaya masyarakat, keagamaan, dan ketenagakerjaan.

\section{e. Kepala Kewilayahan / Kepala Dusun}

Kepala Kewilayahan atau sebutan lainnya berkedudukan sebagai unsur satuan tugas kewilayahan yang bertugas membantu Kepala Desa dalam pelaksanaan tugasnya di wilayahnya.Kepala Kewilayahan atau sebutan lainnya memiliki fungsi:

1) Pembinaan ketentraman dan ketertiban, pelaksanaan upaya perlindungan masyarakat, mobilitas kependudukan, dan penataan dan pengelolaan wilayah.

2) Mengawasi pelaksanaan pembangunan di wilayahnya.

3) Melaksanakan pembinaan kemasyarakatan dalam meningkatkan kemampuan dan kesadaran masyarakat dalam menjaga lingkungannya.

4) Melakukan upaya-upaya pemberdayaan masyarakat dalam menunjang kelancaran penyelenggaraan pemerintahan dan pembangunan.

\section{Pemilihan Kepala Desa / Pilkades}

Pemilihan Kepala Desa merupakan sarana pembentukan demokrasi di desa untuk menumbuh kembangkan partisipasi masyarakat guna melahirkan pemerintah yang baik dan aspiratif. Di samping, dapat menciptakan demokrasi lokal sebagai basis dari pergumulan proses demokrasi secara nasional yang memiliki arti pembelajaran menuju proses pendewasaan politik.

Pemilihan Kepala Desa, atau seringkali disingkat Pilkades adalah suatu pemilihan Kepala Desa secara langsung oleh warga desa setempat. Berbeda dengan Lurah yang merupakan Pegawai Negeri Sipil, Kepala Desa merupakan jabatan yang dapat diduduki oleh warga biasa.Pilkades serentak yang telah diatur dalam Peraturan Pemerintah Nomor 43 Tahun 2014 tentang pelaksanaan Undang-Undang Nomor 6 Tahun 2014 Tentang Desa dan Peraturan Menteri Dalam Negeri Nomor 112 Tahun 2014 Tentang Pemilihan Kepala Desa, Peraturan Daerah Kabupaten Karanganyar No. 19 Tahun 2015 tentang Kepala Desa serta Peraturan Daerah Nomor 15 tahun 2018 tentang Perubahan Perda No. 19 Tahun 2015 tentang Kepala Desa. 
Dalam rangka perwujudan prinsip demokrasi, maka kepala desa dipilih langsung oleh dan dari penduduk desa Warga Negara Republik Indonesia yang telah memenuhi persyaratan dengan masa jabatan 6 (enam) tahun terhitung sejak tanggal pelantikan. Kepala desa dapat menjabat paling banyak 3 (tiga) kali masa jabatan secara berturut-turut atau tidak secara berturut-turut. Sedangkan pengisian jabatan dan masa jabatan Kepala Desa Adat berlaku ketentuan hukum adat di desa adat sepanjang masih hidup dan sesuai dengan perkembangan masyarakat serta prinsip Negara Kesatuan Republik Indonesia yang ditetapkan dalam peraturan Daerah Kabupaten / Kota dengan berpedoman pada peraturan pemerintah. (UU No. 6 Tahun 2014)

\section{Syarat-syarat menjadi kepala desa}

Kepala desa dipilih langsung melalui pemilihan kepala desa oleh penduduk desa setempat. Syarat-syarat untuk menjadi calon kepala desa sesuai pasal 33 UU No. 6 Tahun 2014 sebagai berikut :

a. warga negara Republik Indonesia;

b. bertakwa kepada Tuhan Yang Maha Esa;

c. memegang teguh dan mengamalkan Pancasila, melaksanakan Undang-Undang Dasar Negara Republik Indonesia Tahun 1945, serta mempertahankan dan memelihara keutuhan Negara Kesatuan Republik Indonesia dan Bhinneka Tunggal Ika;

d. berpendidikan paling rendah tamat sekolah menengah pertama atau sederajat;

e. berusia paling rendah 25 (dua puluh lima) tahun pada saat mendaftar;

f. bersedia dicalonkan menjadi Kepala Desa;

g. terdaftar sebagai penduduk dan bertempat tinggal di Desa setempat paling kurang 1 (satu) tahun sebelum pendaftaran;

h. tidak sedang menjalani hukuman pidana penjara;

i. tidak pernah dijatuhi pidana penjara berdasarkan putusan pengadilan yang telah mempunyai kekuatan hukum tetap karena melakukan tindak pidana yang diancam dengan pidana penjara paling singkat 5 (lima) tahun atau lebih, kecuali 5 (lima) tahun setelah selesai menjalani pidana penjara dan mengumumkan secara jujur dan terbuka kepada publik bahwa yang bersangkutan pernah dipidana serta bukan sebagai pelaku kejahatan berulang-ulang;

j. tidak sedang dicabut hak pilihnya sesuai dengan putusan pengadilan yang telah mempunyai kekuatan hukum tetap;

k. berbadan sehat;

1. tidak pernah sebagai Kepala Desa selama 3 (tiga) kali masa jabatan; dan

m. syarat lain yang diatur dalam Peraturan Daerah. 
CIVICS EDUCATION AND SOCIAL SCIENSE JOURNAL(CESSJ)

Volume 2 Nomor 2 Edisi Bulan Desember 2020

\section{Prinsip-prinsip pelaksanaan pemilihan kepala desa}

Prinsip-prinsip dalam pelaksanaan pemilihan kepala desa berdasarkan pasal 34 UU No. 6 Tahun 2014 adalah :

a. Kepala Desa dipilih langsung oleh penduduk Desa.

b. Pemilihan Kepala Desa bersifat langsung, umum, bebas, rahasia, jujur, dan adil.

c. Pemilihan Kepala Desa dilaksanakan melalui tahap pencalonan, pemungutan suara, dan penetapan.

d. Dalam melaksanakan pemilihan Kepala Desa sebagaimana dimaksud pada ayat (2), dibentuk panitia pemilihan Kepala Desa.

e. Panitia pemilihan sebagaimana dimaksud pada ayat (4) bertugas mengadakan penjaringan dan penyaringan bakal calon berdasarkan persyaratan yang ditentukan, melaksanakan pemungutan suara, menetapkan calon Kepala Desa terpilih, dan melaporkan pelaksanaan pemilihan Kepala Desa.

f. Biaya pemilihan Kepala Desa dibebankan pada Anggaran Pendapatan dan Belanja Daerah Kabupaten/Kota.

\section{Tahapan Pemilihan Kepala Desa}

Pada tahap pemilihan kepala desa berdasarkan UU No. 6 Tahun 2014, dilaksanakan kegiatan-kegiatan sebagai berikut :

a. Bakal calon Kepala Desa yang telah memenuhi persyaratan ditetapkan sebagai calon Kepala Desa oleh panitia pemilihan Kepala Desa.

b. Calon Kepala Desa yang telah ditetapkan diumumkan kepada masyarakat Desa di tempat umum sesuai dengan kondisi sosial budaya masyarakat Desa.

c. Calon Kepala Desa dapat melakukan kampanye sesuai dengan kondisi sosial budaya masyarakat Desa dan ketentuan peraturan perundang-undangan.

d. Calon Kepala Desa yang dinyatakan terpilih adalah calon yang memperoleh suara terbanyak.

e. Panitia pemilihan Kepala Desa menetapkan calon Kepala Desa terpilih.

f. Panitia pemilihan Kepala Desa menyampaikan nama calon Kepala Desa terpilih kepada Badan Permusyawaratan Desa paling lama 7 (tujuh) hari setelah penetapan calon Kepala Desa terpilih.

g. Badan Permusyawaratan Desa paling lama 7 (tujuh) hari setelah menerima laporan panitia pemilihan menyampaikan nama calon Kepala Desa terpilih kepada Bupati/Walikota.

h. Bupati/Walikota mengesahkan calon Kepala Desa terpilih menjadi Kepala Desa paling lama 30 (tiga puluh) hari sejak tanggal diterimanya penyampaian hasil pemilihan dari panitia pemilihan Kepala Desa dalam bentuk keputusan Bupati/Walikota. 
i. Dalam hal terjadi perselisihan hasil pemilihan Kepala Desa, Bupati/Walikota wajib menyelesaikan perselisihan dalam jangka waktu sesuai dengan peraturan yang berlaku.

j. Calon Kepala Desa terpilih dilantik oleh Bupati/Walikota atau pejabat yang ditunjuk paling lama 30 (tiga puluh) hari setelah penerbitan keputusan Bupati/Walikota.

k. Sebelum memangku jabatannya, Kepala Desa terpilih bersumpah/berjanji.

Sumpah/janji sebagaimana dimaksud pada ayat (2) sebagai berikut: "Demi Allah/Tuhan, saya bersumpah/berjanji bahwa saya akan memenuhi kewajiban saya selaku Kepala Desa dengan sebaikbaiknya, sejujur-jujurnya, dan seadil-adilnya; bahwa saya akan selalu taat dalam mengamalkan dan mempertahankan Pancasila sebagai dasar negara; dan bahwa saya akan menegakkan kehidupan demokrasi dan Undang-Undang Dasar Negara Republik Indonesia Tahun 1945 serta melaksanakan segala peraturan perundangundangan dengan selurus-lurusnya yang berlaku bagi Desa, daerah, dan Negara Kesatuan Republik Indonesia”.

\section{METODE}

Penelitian ini menggunakan metode kualitatif dengan jenis penelitian deskriptif yang bertujuan untuk menggambarkan bagaimana pelaksanaan Pemilihan Kepala Desa Gebyog Kecamatan Mojogedang Kabupaten Karanganyar Tahun 2020.

Pendekatan yang digunakan dalam penelitian ini adalah pendekatan kualitatif. Pendekatan kualitatif adalah proses penelitian dan pemahaman yang berdasarkan metodologi yang menyelidiki suatu fenomena sosial dan manusia. Bogdan dan Taylor (Moleong, 2007 : 3) mengemukakan bahwa metodologi kualitatif merupakan prosedur penelitian yang menghasilkan data deskriptif berupa kata-kata tertulis maupun lisan dari orang-orang dan perilaku yang diamati. Pendekatan kualitatif ini menghasilkan suatu uraian yang mendalam tentang ucapan. Tulisan dan atau perilaku yang sedang diamati dari suatu individu, kelompok, masyarakat, dan atau sebuah organisasi tertentu dalam kehidupan sehari-hari yang dikaji dari sudut pandang yang utuh dan komprehensif. Penelitian ini dilaksanakan di Desa Gebyog Kecamatan Mojogedang Kabupaten Karanganyar yang telah melaksanakan pemilihan Kepala Desa (Pilkades) sehingga penulis tertarik untuk melakukan penelitian.

Data dalam penulis, dalam penelitian ini menggunakan sumber data yang diklasifikasikan berdasarkan cara perolehannya, yaitu: 


\section{Data Primer}

Menurut Subagyo mengemukakan data primer yaitu "Data yang diperoleh secara langsung dari masyarakat baik yang dilakukan melalui wawancara, observasi, dan alat lainnya merupakan data primer. Data primer diperolehnya sendiri secara mentah-mentah dari masyarakat dan masih memerlukan analisi lebih lanjut". Dalam penelitian ini penulis melakukan pendataan primer melalui wawancara dengan responden yang dipilih di lapangan.

\section{Data Sekunder}

Subagyo mengatakan bahwa, data yang diperoleh dari atau berasal dari bahan kepustakaan disebut sebagai data sekunder. Data ini biasanya digunakan untuk melengkapi data primer, mengingat bahwa data primer dapat dikatakan sebagai data praket yang ada di lapangan, karena penerapan sesuatu teori.

Untuk memperoleh data primer dan data sekunder, kegiatan pengumpulan data. Pengumpulan data adalah prosedur yang sistematis dan standar untuk memperoleh data yang diperoleh. Oleh karena itu terdapat hubungan erat antara teknik pengumpulan data dengan kualitas data. Pengumpulan data yang baik akanmenghasilkan data yang berkualitas. Data yang berkualitas tentunya dapat menjawab perumusan masalah yang dirumuskan.

Dalam penelitian ini, digunakan cara pengumpulan data sebagai berikut:

1. Penelitian lapangan (field Researh)

Penelitian lapangan adalah cara memperoleh data dengan mengadakan wawancara atau tanya jawab dengan berbagai pihak yang berkaitan dengan penelitian ini. Wawancara adalah cara untuk memperoleh informasi dengan bertanya langsung kepada orang-orang yagn diwawancarai (Soemitro, 1990: 57) untuk penelitian lapangan dilakukan dengan :

a. Observasi, yaitu melakukan pengamatan langsung pada obyek yang bersangkutan, yaitu realitas pemilihan kepala desa di Desa Gebyog Kecamatan Mojogedang Kabupaten Karanganyar kaitannya dengan peraturan pelaksanaan pemilihan kepala desa.

b. Interview, yaitu percakapan dengan maksud tertentu yang dilakukan oleh dua pihak yaitu pewawancara (interviewer) yang mengajukan pertanyaan dan diwawancarai (interviewe) yang memberikan jawabatan atas pertanyaan itu (Moleong, 2006: 186).

2. Penelitian kepustakaan (library research) adalah suatu penelitian yang dilakukan dengan cara membaca literatur-literatur yang ada kaitannya dengan permasalahan dalam skripsi ini. Di dalam penelitian ini, literatur merupakan bahan referensi yang digunakan untuk menunjang keberhasilan penelitian ini. 
3. Metode Dokumentasi yaitu mencari data mengenai hal-hal atau variabel yang berupa catatan, transkrip, buku, surat kabar, majalah, prasasti, notulen rapat, agenda dan sebagainya (Arikunto, 2006: 158). Dokumentasi diperlukan untuk memperkuat data-data yang diperoleh melalui sumbersumber tersebut di atas.

Data yang telah terkumpul melalui observasi dan wawancara langsung dalam penelitian ini selanjutnya dianalisa secara kualitatif, yaitu dengan menguraikan dan menjelaskan hasil-hasil penelitian dalam bentuk kata-kata lisan maupun tertulis, pengolahan data dalam penelitian kualitatif dilakukan dengan cara mengklasifikasi atau mengkategorikan data berdasarkan beberapa tema sesuai fokus penelitian.

Menurut Sugiyono (2014: 428) menjelaskan analisis data adalah proses mencari dan menyusun secara sistematis data yang diperoleh dari hasil wawancara, catatan lapangan, dokumentasi dengan cara mengorganisasikan data ke dalam kategori, menjabarkan kedalam unit-unit, melakukan sinetesa, menyusun ke dalam pola, memilih mana yang penting dan akan dipelajari dan membuat kesimpulan sehingga mudah dipahami oleh diri sendiri maupun oleh orang lain.

Tujuan dari analisis data adalah untuk mendeskripsikan sebuah data sehingga bisa di pahami, dan juga untuk membuat kesimpulan atau menarik kesimpulan mengenai karakteristik populasi yang berdasarkan data yang diperoleh dari sampel, yang biasanya ini dibuat dengan dasar pendugaan dan pengujian hipotesis. (https://pastiguna.com/teknik-analisis-data )

Adapun skema model analisis interatif menurut H. B. Sutopo (2002: 187) yaitu sebagai berikut :

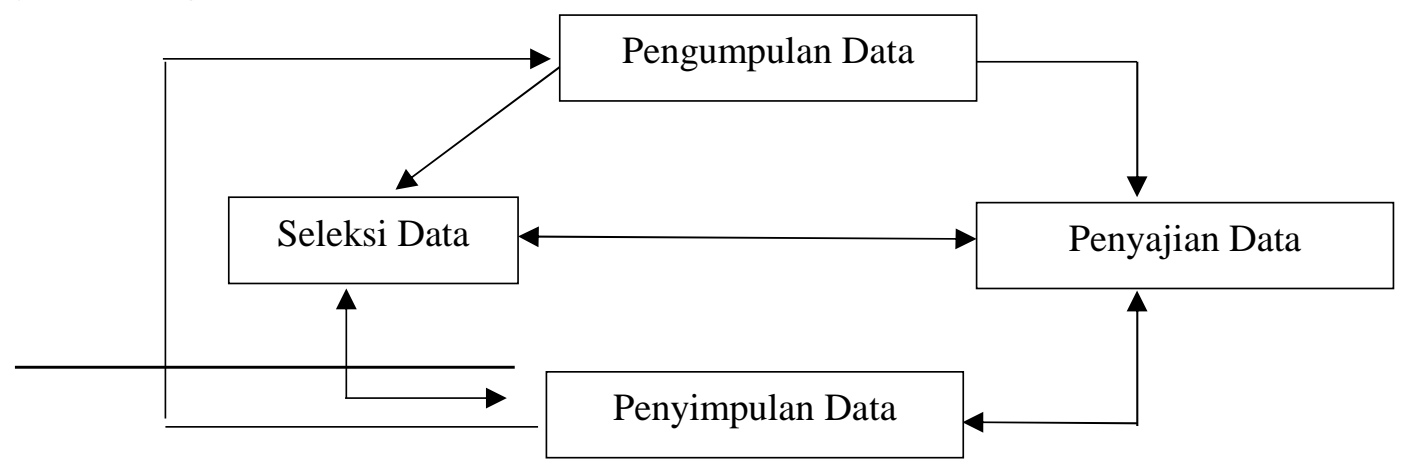

\section{HASIL PENELITIAN DAN PEMBAHASAN}

\section{Deskripsi Pelaksanaan PILKADES Desa Gebyog}

Tata cara Pemilihan Kepala Desa (Pilkades) di Desa Gebyog pada dasarnya sama dengan pelaksanaan Pilkades di desa-desa lainnya yang ada di Kabupaten Karanganyar. Dasar hukum yang digunakan sebagai pedoman pelaksanaan pemilihan kepala desa (Pilkades) adalah PeraturanBupati No. 22 Tahun 2019 tentang perubahan kedua atas Peraturan Bupati nomor 66 tahun 2018 tentang kepala desa. 
Pilkades di Desa Gebyog yang diselenggarakan pada tanggal 11 Maret 2020 pada dasarnya adalah untuk mewujudkan adanya kepala desa yang dapat memimpin pemerintahan desa Gebyog. Hal tersebut penting karena penyelenggaraan pemerintahan desa yang memberikan hasil yang baik dengan pemberdayaan seluruh masyarakat, hanya akan terwujud jika ada kepala desa yang mampu memberikan kemakmuran, rasa tanggungjawab bermusyawarah, adil serta demokratis. Dalam hal ini kepala desa merupakan figure yang penting dalam membentuk strategi desa yang peranannya untuk memajukan pemikiran masyarakat desa dan pemerintahan desa setempat.

Dalam pelaksanaan proses pemilihan kepala desa (pilkades) di Kabupaten Karanganyar Tahun 2020 terdapat serangkaian tahapan yang harus dilalui. Berdasarkan ketentuan pasal 4, 5, 6, dan 7 Peraturan Daerah Kabupaten Karanganyar Nomor 19 Tahun 2015 tentang kepala desa diselenggarakan melalui 4 tahapan, yaitu :

\section{Tahapan Persiapan, meliputi:}

a) Pembentukan Panitia Pemilihan

Sebelum Pemilihan Kepala Desa (Pilkades) dilaksanakan Bupati membentuk Panitia Pemilihan Kepala Desa Tingkat Kabupaten dan di Kecamatan dibentuk Panitia Pemilihan Kepala Desa Tingkat Kecamatan yang terdiri dari unsur Muspika, Danramil, Sekcam serta pejabat yang ditunjuk lainnya. BPD memberitahukan kepada kepala desa mengenai akan berakhirnya masa jabatan kepala desa secara tertulis dalam waktu 6 (enam) bulan sebelum masa jabatannya berakhir. Kepala Desa menyampaikan laporan akhir masa jabatan kepada Bupati dalam waktu 30 (tiga puluh) hari setelah pemberitahuan masa akhir masa jabatan. BPD membentuk Panitia Pemilihan Kepala Desa Tingkat Desa dalam waktu 10 (sepuluh) hari setelah pemberitahuan akhir masa jabatan dengan keputusan BPD. Panitia pemilihan kepala desa tingkat desa terdiri dari unsur perangkat desa, pengurus lembaga kemasyarakatan desa, dan tokoh masyarakat desa.

Pembentukan Panitia Pemilihan Kepala Desa Tingkat Desa dilaksanakan pada tanggal 1 Nopember 2019 bertempat di Balai Desa Gebyog. Panitia Pemilihan Kepala Desa Tingkat Desa bertugas :

1) merencanakan, mengkoordinasikan, menyelenggarakan, mengawasi, dan mengendalikan semua tahapan pelaksanaan pemilihan;

2) merencanakan dan mengajukan biaya pemilihan kepada Bupati melalui Camat;

3) melakukan pendaftaran dan penetapan pemilih;

4) mengadakan penjaringan dan penyaringan bakal calon;

5) menetapkan calon yang telah memenuhi persyaratan;

6) menetapkan tata cara pelaksanaan pemilihan; 
7) menetapkan tata cara pelaksanaan kampanye;

8) memfasilitasi penyediaan peralatan, perlengkapan dan tempat pemungutan suara;

9) melaksanakan pemungutan suara;

10) menetapkan hasil rekapitulasi penghitungan suara dan mengumumkan hasil pemilihan;

11) menetapkan calon Kepala Desa terpilih; dan

12) melakukan evaluasi dan pelaporan pelaksanaan pemilihan.

Panitia Pemilihan Kepala Desa Tingkat Desa bersifat mandiri dan tidak memihak. Pembentukan Panitia Pemilihan Kepala Desa Tingkat Desa disampaikan secara tertulis oleh BPD kepada Bupati melalui Camat. Panitia membuat Tata Tertib Pemilihan Kepala Desa Gebyog periode 2020-2026 yang menjadi landasan panitia dalam menjalankan tugasnya.

Berdasarkan lampiran Keputusan Panitia Pemilihan Kepala Desa Tingkat desa Gebyog nomor 1 tahun 2019 tentang tata Tertib Pemilihan Kepala Desa Gebyog menyebutkan bahwa pemilih yang menggunakan hak pilih harus terdaftar sebagai pemilih. Persyaratan sebagai pemilih sebagai berikut :

1) Penduduk desa bersangkutan yang pada hari pemungutan suara pemilihan kepala desa sudah berumur 17 (tujuh belas) tahun atau sudah/pernah menikah;

2) Nyata-nyata tidak sedang terganggu jiwa/ingatannya;

3) Tidak sedang dicabut hak pilihnya berdasarkan putusan pengadilan yang telah memperoleh kekuatan hukum tetap; dan

4) Berdomisili di desa bersangkutan sekurang-kurangnya 6 (enam) bulan sebeluh disahkan daftar pemilih sementara yang dibuktikan dengan Kartu Tanda Penduduk atau dokumen kependudukan lain sesuai ketentuan peraturan yang berlaku.

Petugas melakukan pendaftaran pemilih yang memenuhi syarat sebagai pemilih. Kemudian daftar nama penduduk desa yang disusun menurut abjad untuk masing-masing RT pada wilayah dusun. Data pemilih dimutakhirkan dan divalidasi sesuai data penduduk di desa. Pemutakhiran dilakukan karena memenuhi syarat usia pemilih, yang sampai dengan hari dan tanggal pemunggutan suara pemilihan sudah berumur 17 (tujuh belas) tahun; belum berumur 17 (tujuh belas) tetapi sudah menikah / pernah menikah; telah meninggal dunia; pindah domisili ke desa lain; belum terdaftar.

PanitiaPemilihan Kepala Desa Tingkat Desa menyusun dan menetapkan Daftar Pemilih Sementara (DPS) pada tanggal 21 November 2019. Total Daftar Pemilih Sementara adalah 5.032 orang. 
Tabel 5.

Rekapitulasi Daftar Pemilih Sementara (DPS) untuk Pemilihan Kepala Desa Gebyog Tahun 2020

\begin{tabular}{|c|l|c|}
\hline \hline No & Nama KepalaKewilayahan /Kadus & JumlahPemilih \\
\hline 1 & Bancak 1 & 735 \\
\hline 2 & Bancak 2 & 946 \\
\hline 3 & Gebyog & 513 \\
\hline 4 & Kalilutung & 904 \\
\hline 5 & Karangmendeng & 1186 \\
\hline 6 & Pencol & 748 \\
\hline \multicolumn{2}{|c|}{ Total jumlahpemilih } & 5.032 \\
\hline
\end{tabular}

Daftar Pemilih Sementara diumumkan kepada warga masyarakat dengan cara menempelkan Daftar Pemilih Sementara pada papan pengumuman desa dan tempat mudah dijangkau masyarakat. Jangka waktu pengumuman selama 3 hari. Dalam jangka waktu pengumuman pemilih atau anggota keluarganya dapat mengajukan perbaikan mengenai penulisan nama dan/atau identitas lainnya. Selain usulan perbaikan pemilih atau anggota keluarga dapat memberikan informasi yang meliputi pemilih yang terdaftar sudah meninggal dunia; pemilih sudah tidak berdomisili di desa tersebut; pemilih yang sudah nikah di bawah umur 17 (tujuh belas) tahun; atau pemilih yang sudah terdaftar tetapi sudah tidak memenuhi persyaratan sebagai pemilih. Apabila usul perbaikan dan informasi diterima, panitia pemilihan kepala desa tingkat desa segera mengadakan perbaikan daftar pemilih sementara. .

Pemilih yang belum terdaftar, secara aktif melaporkan kepada panitia pemilihan kepala desa tingkat desa melalui pengurus RT/RW dan dimasukkan sebagai pemilih tambahan. Pencatatan pemilih tambahan dilaksankan 3 (tiga) hari setelah berakhirnya pengumuman Daftar Pemilih Sementara. Daftar pemilih tambahan diumumkan oleh panitia pemilihan kepala desa tingkat desa pada tempat-tempat yang mudah dijangkau oleh masyarakat. Jangkat waktu pengumuman daftar pemilih tambahan dilaksanakan 3 hari terhitung sejak berakhirnya jangka waktu penyusunan daftar pemilih tambahan.

Panitia Pemilihan Kepala Desa Tingkat Desa Gebyog menetapkan dan mengumumkan daftar pemilih sementara yang sudah diperbaiki dan daftar pemilih tambahan dan disahkan 
sebagai Daftar Pemilih Tetap (DPT) pada tanggal 09 Desember 2019. Total Daftar Pemilih Tetap Desa Gebyog adalah 5.046.

Tabel6:

Rekapitulasi DaftarPemilihTetap PilkadesDesa Gebyog

\begin{tabular}{|l|l|c|}
\hline \hline No & $\begin{array}{l}\text { Nama KepalaKewilayahan } \\
\text { /Kadus }\end{array}$ & JumlahPemilih \\
\hline 1 & Bancak 1 & 735 \\
\hline 2 & Bancak 2 & 948 \\
\hline 3 & Gebyog & 514 \\
\hline 4 & Kalilutung & 910 \\
\hline 5 & Karangmendeng & 1188 \\
\hline 6 & Pencol & 751 \\
\hline \multicolumn{2}{|l|}{ Total jumlahpemilih } & 5.046 \\
\hline
\end{tabular}

Daftar Pemilih Tetap (DPT) diumumkan di tempat yang strategis di desa untuk diketahui oleh masyarakat dan jangka waktu pengumuman Daftar Pemilih Tetap selama 3 hari sejak berakhirnya jangka waktu penyusunan Daftar Pemilih Tetap.

\section{Tahapan Pencalonan, meliputi :}

a. Penjaringan

Panitia Pemilihan Kepala Desa Tingkat Desa melaksanakan kegiatan penjaringan dan penyaringan bakal Calon Kepala Desa pada waktu yang telah ditetapkan.Panitia Pemilihan Kepala Desa Tingkat Desa mengumumkan dimulainya pendaftaran bakal Calon Kepala Desa di tempat-tempat umum yang dapat diketahui masyarakat luas.Pelaksanaan pendaftaran bakal Calon Kepala Desa Gebyog dilaksanakan mulai tanggal 13, 16, 17, 18, 20, 23, 24, 25, 25, 26, 27 Desember 2019. Pukul 08.00 s/d 14.00 WIB (jam kerja kantor). Tempat di Kantor DesaGebyog.

Bakal Calon Kepala Desa yang akan mendaftarkan diri mengajukan surat lamaran pencalonan Kepala Desa yang ditulis tangan di atas kertas bermeterai cukup ditujukan kepada Panitia Pemilihan Kepala Desa Tingkat Desa dengan dilengkapi persyaratan yang ditentukan dan dibuat rangkap 3 (tiga) masing-masing untuk Panitia Pemilihan Kepala Desa Tingkat Desa, Camat, dan Bupati.

Berdasarkan hasil Rapat Penutupan Pendaftaran Bakal Calon Kepala Desa Pemilihan Kepala Desa Gebyog Tahun 2020 diperoleh 
Bakal Calon Kepala Desa yang telah mendaftarkan diri sejumlah 6 (enam), yaitu :

1) Sdr. Muhammad Riyadi umur 54 tahun, pendidikan Sarjana Pekerjaan Wiraswasta alamat Bancak 1 Rt 04 Rw 2.

2) Sdr. Sukiyo umur 37 tahun pendidikan SLTA pekerjaan mantan kepala desa alamat Karangmendeng Rt 02 Rw 12.

3) Sdr. Sularno umur 50 tahun pendidikan SLTA pekerjaan swasta alamat Gedangan Rt 02 Rw 10.

4) Sdr. Suprihatin umur 29 tahun, pendidikan SLTA pekerjaan swasta alamat Karangmendeng Rt 01 Rw 12.

5) Sdr. Asih Setyowati umur 44 tahun, pendidikan SLTA pekerjaan wiraswasta alamat Bancak 1 Rt 04 Rw 02.

6) Sdr. Sugiyarto umur 39 tahun, pendidikan SLTP pekerjaan wiraswasta alamat Karangmendeng Rt 02 RW 12.

b. Penelitian berkas persyaratan calon kepala desa

Panitia Pemilihan Kepala Desa Tingkat Desa melakukan penelitian terhadap persyaratan bakal calon meliputi penelitian kelengkapan dan keabsahan administrasi pencalonan. Penelitian kelengkapan dan keabsahan administrasi disertai klarifikasi pada instansi yang berwenang yang dilengkapi dengan surat keterangan dari yang berwenang. Panitia Pemilihan Kepala Desa Tingkat Desa mengumumkan hasil penelitian kepada masyarakat untuk memperoleh masukan. Masukan masyarakat wajib diproses dan ditindak lanjuti Panitia Pemilihan Kepala Desa Tingkat Desa. Panitia Pemilihan Kepala Desa Tingkat Desa meneliti kelengkapan persyaratan administrasi, melakukan klarifikasi, serta menetapkan dan mengumumkan nama Calon Kepala Desa dalam jangka waktu 20 (dua puluh) hari.

Berdasarkan Keputusan Panitia Pemilihan Kepala Desa Tingkat Desa, Desa Gebyog nomor 01 tahun 2020 tentang Perubahan Atas Keputusan Panitia Pemilihan Tingkat Desa tentang Tata Tertib Pemilihan Kepala Desa Tingkat Desa bahwa klarifikasi persyaratan administrasi Balon Kades dan pemberitahuan hasilnya secara tertulis tanggal 8 sampai 14 Januari 2020. Balon Kades diberi kesempatan melengkapi keabsahan berkas tanggal 15 sampai 16 Januari 2020 pukul 14.00 WIB. Pengumuman hasil pemeriksaan berkas persyaratan Balon Kades kepada masyarakat tanggal 17 Januari 2020 pukul 10.00 WIB.

c. Penetapan Calon Kepala Desa

Panitia Pemilihan Kepala Desa Tingkat Desa telah melaksanakan penelitian berkas persyaratan administrasi Bakal Calon Kepala Desa dan mengumumkan hasil penelitian berkas persyaratan Bakal Calon Kepala Desa yang dinyatakan memenuhi persyaratan administrasi dan 
berhak ditetapkan menjadi Calon Kepala Desa sejumlah 3 (tiga) orang yaitu:

(1) Sdr. Muhammad Riyadi umur 54 tahun, pendidikan Sarjana Pekerjaan Wiraswasta alamat Bancak 1 Rt 04 Rw 2.

(2) Sdr. Sularno umur 50 tahun pendidikan SLTA pekerjaan swasta alamat Gedangan Rt 02 Rw 10.

(3) Sdr. Sugiyarto umur 39 tahun, pendidikan SLTP pekerjaan wiraswasta alamat Karangmendeng Rt 02 RW 12.

Setelah ditetapkan sebagai calon kepala desa dilaksanakan penetapan nomor urut calon kepala desa. Berdasarkan Surat Keputusan Panitia Pemilihan Kepala Desa Tingkat Desa Desa Gebyog nomor 01 tahun 2019 tentang Tata Tertib Pemilihan Kepala Desa menyebutkan bahwa pengundian nomor urut calon kepala desa dilaksanakan di Balai Desa Gebyog dihadiri oleh masing-masing calon kepala desa. Calon kepala desa diperbolehkan mengajak keluarga dan pendukungnya maksimal 30 orang. Pengambilan undian nomor urut calon kepala desa dimulai oleh calon kepala desa sesuai nomor urut pendaftaran. Nomor urut yang sudah diambil oleh calon kepala desa tidak boleh dikembalikan atau ditukar dengan calon kepala desa lainnya. Pengambilan nomor urut calon kepala desa dilaksanakan pada tanggal 23 Januari 2020 di Balai Desa Gebyog.

d. Pelaksanaan Kampanye

Kampanye pemilihan kepala desa diatur dalam pasal 27 - 32 Permendagri 112 tahun 2014 tentang Kepala Desa, pedoman aturan kampanye pemilihan kepala desa adalah sebagai berikut:

1) Calon Kades dapat melakukan kampanye sesuai dengan kondisi sosial budaya masyarakat Desa.

2) Pelaksanaan kampanye dalam jangka waktu 3 (tiga) Hari sebelum dimulainya masa tenang.

3) Kampanye dilakukan dengan prinsip jujur, terbuka, dialogis serta bertanggung jawab.

4) Kampanye memuat visi dan misi bila terpilih sebagai kepala desa. Visi merupakan keinginan yang ingin diwujudkan dalam jangka waktu masa jabatan kepala desa. Misi berisi program yang akan 5) dilaksanakan dalam rangka mewujudkan visi.

6) Kampanye dilaksanakan melalui: pertemuan terbatas; tatap muka; dialog; penyebaran bahan Kampanye kepada umum; pemasangan alat peraga di tempat Kampanye dan di tempat lain yang ditentukan oleh panitia pemilihan; dan kegiatan lain yang tidak melanggar peraturan perundang-undangan. 
Berdasarkan surat Keputusan Panitia Pemilihan Kepala Desa Tingkat Desa Desa Gebyog nomor 01 tahun 2019 tentang Tata Tertib Pemilihan Kepala Desa menyebutkan bahwa

1) Penyampaian naskah visi dan misi serta kampanye Penyampaian naskah visi dan misi calon kepala desa diserahkan kepada Panitia Pemilihan Kepala Desa tingkat desa pada tanggal 6 maret 2020. Penyampaian visi dan misi oleh calon kepala desa dilaksanakan pada tanggal 9 Maret 2020 di Balai Desa Gebyog pukul 09.00 WIB dengan cara pidato sesuai nomor urut Calon Kepala Desa. Masing-masing calon kepala desa diberi waktu maksimal 20 menit untuk menyampaikan visi dan misi. Penyampaian visi dan misi dihadiri oleh undangan yang dientukan oleh panitia pemilihan kepala desa tingakt desa. Calon kepala desa diperbolehkan mengajak keluarga dan pendukung maksimal 30 orang. Setelah pelaksanaan penyampaian visi dan misi oleh calon kepala desa dilanjutkan dengan kampanye, waktu kampanye sampai dengan $24.00 \mathrm{WIB}$. Semua pihak yang hadir wajib menjaga suasana tetap tenang, kondusuf dan nyaman selama proses berlangsung.

2) Sosialiasi calon kepala desa

Panitia pemilihan kepala desa tingkat desa menyediakan alat sosialisasi calon kepala desa, dan calon kepala desa diperkenankan membuat alat sosialisasi sendiri sesuai dengan ketentuan yang berlaku. Alat peraga kampanye yang disediakan panitia pemilihan kepala desa berupa baliho, poster, dan spanduk. Permasangan alat peraga kampanya di titik lokasi yang telah ditentukan oleh panitia pemilihan kepala desa di tingkat desa.

3) Masa Tenang

Tanggal 10 Maret 2020 adalah hari tenang kampanye. Semua alat peraga kampanye yang terpasang di wilayah desa Gebyog diamankan oleh panitia pemilihan kepala desa tingkat desa.

\section{Pemunggutan Suara}

Sebelum melaksanakan pemungutan suara Kelompok Penyelenggaraan Pemunggutan Suara (KPPS) Pemilihan Kepala Desa Gebyog melaksanakan kegiatan persiapan pemungutan suara pemilihan kepala desa. Adapun kegiatannya sebagai berikut :

1) Pembukaan kotak suara;

2) Pengeluaran seluruh isi kotak suara;

3) Mengidentifikasi jenis dokumen dan peralatan yang terdiri dari DPT, suarat suara, alat pencoblos, bantalan, alat tulis, tinta warna ungu, kertas plano perhitungan suara, berita acara dan peralatan lain.

4) Perhitungan jumlah setiap jenis dokumen dan peralatan 
5) Memperlihatkan kepada pemilih dan calon kepala desa atau saksi calon kepala desa bahwa kotak suara dalam keadaan kosong kemudian menutupnya kembali, mengunci, dan menyegel dengan menggunakan kertas yang dibubuhi stempel Panitia Pemilihan Kepala Desa Tingkat Desa;

6) Mengumumkan nama dan nomor urut Calon Kepala Desa, jumlah surat suara, jumlah pemilih, tata cara pemungutan suara serta keabsahan suara.

Panitia pemilihan kepala desa tingkat desa mempersiapkan sarana dan prasarana untuk untuk pemilihan kepala desa, antara lain: bilik suara, surat suara, kotak surat suara, surat undangan, dan kelengkapan pemungutan suara lainnya yang diperlukan. Panitia pemilihan kepala desa tingkat desa wajib menjamin agar pelaksanaan pemilihan kepala desa dapat berjalan secara demokratis, tertib, aman, lancar dan teratur, serta menjamin pelaksanaan pemungutan suara berlangsung secara langsung, umum, bebas, rahasia, jujur dan adil. Pelaksanaan pemungutan suara dimulai pukul 08.00 WIB sampai pukul 13.00 WIB. Ketentuan batas waktu pemungutan dengan tetap memberi kesempatan kepada pemilih yang telah melaksanakan konfirmasi kehadiran kepada panitia pemilihan kepala desa tingkat desa paling lambat pukul 13.00 WIB. Pada saat pemungutan dan perhitungan suara berlangsung para calon kepala desa harus berada di tempat pemungutan dan perhitungan suara, yang telah ditentukan oleh panitia pemilihan kepala desa tingkat desa kecuali dengan alasan yang dapat dipertanggungjawabkan.

Pemungutan suara dilaksanakan pada waktu yang telah ditetapkan oleh Panitia Pemilihan Kepala Desa Tingkat Kabupaten, yaitu serentak pada tanggal 11 Maret 2020. Proses pemungutan suara dilakukan oleh pemilih secara tertutup melalui pencoblosan pada surat suara yang berisi nomor, foto dan nama calon kepala desa yang berhak dipilih oleh pemilih yang dilakukan pada bilik-bilik suara yang telah disediakan di TPS tempat pemilih terdapat dalam DPT.

\section{Penetapan}

a. Perhitungan Suara dan penetapan calon terpilih

Perhitungan suara dilakukan oleh Panitia Pemilihan Kepala Desa tingkat Desa setelah pemungutan suara berakhir. Perhitungan disaksikan oleh calon kepala desa atau dapat diwakilkan, masingmasing saksi dari Calon Kepala Desa, BPD, serta masyarakat. Setelah perhitungan selesai dilakukan lalu Ketua Panitia Pemilihan Kepala Desa Tingkat Desa mengumumkan hasil perhitungan suara yang dinyatakan sah dan mengumumkan calon kepala desa terpilih.

Penghitungan suara di TPS dilakukan oleh panitia setelah pemungutan suara berakhir. Sebelum penghitungan suara dimulai panitia pemilihan menghitung: 
1) jumlah pemilih yang memberikan suara berdasarkan salinan daftar pemilih tetap;

2) jumlah surat suara yang tidak terpakai; dan

3) jumlah surat suara yang dikembalikan oleh pemilih karena rusak atau keliru dicoblos.

Penghitungan suara dilakukan oleh panitia pemilihan dan dapat dihadiri dan disaksikan oleh saksi calon, BPD, pengawas, dan warga masyarakat. Saksi calon dalam penghitungan suara, harus membawa surat mandat dari calon yang bersangkutan dan menyerahkannya kepada Ketua panitia. Panitia membuat berita acara hasil penghitungan suara yang ditandatangani oleh ketua dan sekurang-kurangnya 2 (dua) orang anggota panitia serta dapat ditandatangani oleh saksi calon.

Pemilih yang hadir pada Kelompok Penyelenggara Pemunggutan Suara (KPPS) pada pemilihan kepala desa Gebyog tahun 2020 dapat dilihat pada tabel 7.

Tabel 7.

Kehadiran Pemilih pada Tempat Pemunggutan Suara Pemilihan Kepala Desa Gebyog Tahun 2002.

\begin{tabular}{|l|l|r|}
\hline \hline No & \multicolumn{1}{|c|}{ Keterangan } & Jumlah \\
\hline 1 & Pemilihhadir & 4243 \\
\hline 2 & Pemilih yang tidakhadir & 803 \\
\hline \multicolumn{2}{|c|}{ Total JumlahDaftarPemilih } & 5046 \\
\hline
\end{tabular}

Berdasarkan tabel tersebut menunjukkan jumlah pemilih yang hadir pada kelompok penyelenggara pemungutan suara pemilihan kepala desa Gebyog sebesar 4243 orang dan pemilih yang tidak hadir 803 orang. Porsentase kehadiran pemilih dapat dilihat pada grafik 4.1

Grafik 4.1

Jumlah pemilih yang hadir pada Pemungutan Suara Pemilihan Kepala Desa Gebyog Tahun 2020

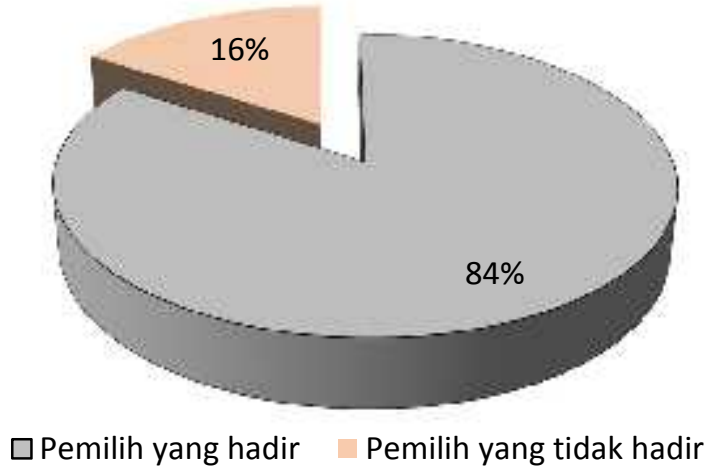

JORNAL PROGDI PPKn, FKIP UNIVET BANTARA SUKOHARJO BEKERJA SAMA DENGANASSOSIASI PROFESI PENDIDIKAN PANCASILA DAN KEWARGANEGARAAN (AP3KNI) JAWA TENGAH 
Perhitungan suara sah pada pemungutan suara diatur dalam Permendagri nomor 112 tahun 2014 tentang pemilihan kepala desa pasal 40 sebagai berikut:

Suara untuk pemilihan Kepala Desa dinyatakan sah apabila:

1) surat suara ditandatangani oleh ketua panitia; dan

2) tanda coblos hanya terdapat pada 1 (satu) kotak segi empat yang memuat satu calon; atau

3) tanda coblos terdapat dalam salah satu kotak segi empat yang memuat nomor, foto dan nama calon yang telah ditentukan; atau

4) tanda coblos lebih dari satu, tetapi masih di dalam salah satu kotak segi empat yang memuat nomor, foto, dan nama calon; atau

5) tanda coblos terdapat pada salah satu garis kotak segi empat yang memuat nomor, foto, dan nama calon.

Proses Perhitungan suara oleh Kelompok Penyelenggara Pemunggutan Suara (KPPS) Pemilihan kepala desa Gebyog dibagi menjadi 3 kelompok. Kelompok Penyelenggara Pemungutan Suara bisa melaksanakan tugasnya secara bersama-sama untuk mempercepat pelaksanaan perhitungan suara. Hasil perhitungan suara di 3 kelompok digabung dan dijumlahkan menjadi 1 (satu), ditulis dalam berita acara hasil perhitungan suara.

Hasil perhitungan kartu suara pada Kelompok Penyelenggara Pemunggutan Suara (KPPS) pada pemilihan kepala desa Gebyog tahun 2020 dapat dilihat pada tabel 8.

Tabel 8.

Perhitungan Kartu Suara pada Kelompok Penyelenggara Pemunggutan Suara (KPPS) Pemilihan Kepala Desa Gebyog

Tahun 2020

\begin{tabular}{|c|l|r|}
\hline \hline No & \multicolumn{1}{|c|}{ Keterangan } & Jumlah \\
\hline 1 & Suara Sah & 4210 \\
\hline 2 & Suara Tidak Sah & 33 \\
\hline \multicolumn{2}{|c|}{ Total Jumlah Pemilih yang hadir } & 4243 \\
\hline
\end{tabular}

Berdasarkan tabel tersebut menunjukkan jumlah kartu suara sah pada Kelompok Penyelenggara Pemungutan Suara Pemilihan Kepala Desa Gebyog Tahun 2020 sebanyak 4210 kartu suara dan kartu suara yang tidak sah / rusah 33 kartu suara. Porsentase kartu suara sah dapat dilihat pada grafik 4.2 


\section{Perhitungan Kartu Suara pada Pemungutan Suara \\ Pemilihan Kepala Desa Gebyog Tahun 2020}

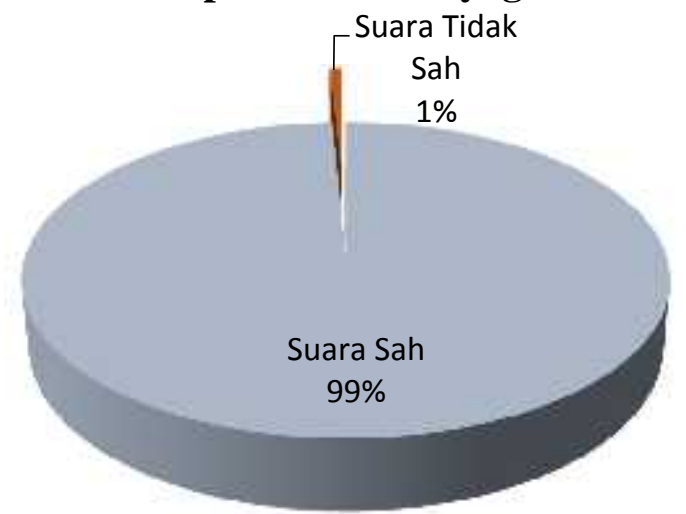

Grafik 4.2.

Kartu Suara Sah pada Kelompok Penyelengara Pemungutan Suara (KPPS) Pemilihan Kepala Desa Gebyog Tahun 2020

Perolehan suara pada tiap-tiap calon kepala desa pada Kelompok Penyelenggara Pemunggutan Suara (KPPS) Pemilihan Kepala Desa Gebyog Tahun 2020 dapat dilihat pada tabel 9.

Tabel 9.

Perolehan Suara Calon Kepala Desa Pada Pemungutan Suara Pemilihan Kepala Desa Gebyog Tahun 2020

\begin{tabular}{|c|l|r|}
\hline \hline $\begin{array}{c}\text { No Urut Calon } \\
\text { Kepala Desa }\end{array}$ & \multicolumn{1}{|c|}{ Nama Calon Kepala Desa } & Jumlah \\
\hline 1 & Muhammad Riyadi & 1578 \\
\hline 2 & Sugiyarto & 1780 \\
\hline 3 & Sularno & 852 \\
\hline \multicolumn{2}{|c|}{ Total Kartu Suara Sah } & 4210 \\
\hline
\end{tabular}

Berdasarkan tabel tersebut menunjukkan perolehan suara Calon nomor 1. Sdr. Muhammad Riyadi memperoleh 1.578 suara; Calon nomor 2. Sdr. Sugiyarto memperoleh 1.780 suara dan Calon nomor 3. Sdr. Sularno memperoleh 852 suara. Porsentase perolehan suara calon kepala desa dapat dilihat pada grafik 4.3. 


\section{Perolehan Suara Calon Kepala Desa pada Pemilihan Kepala Desa Gebyog Tahun 2020}

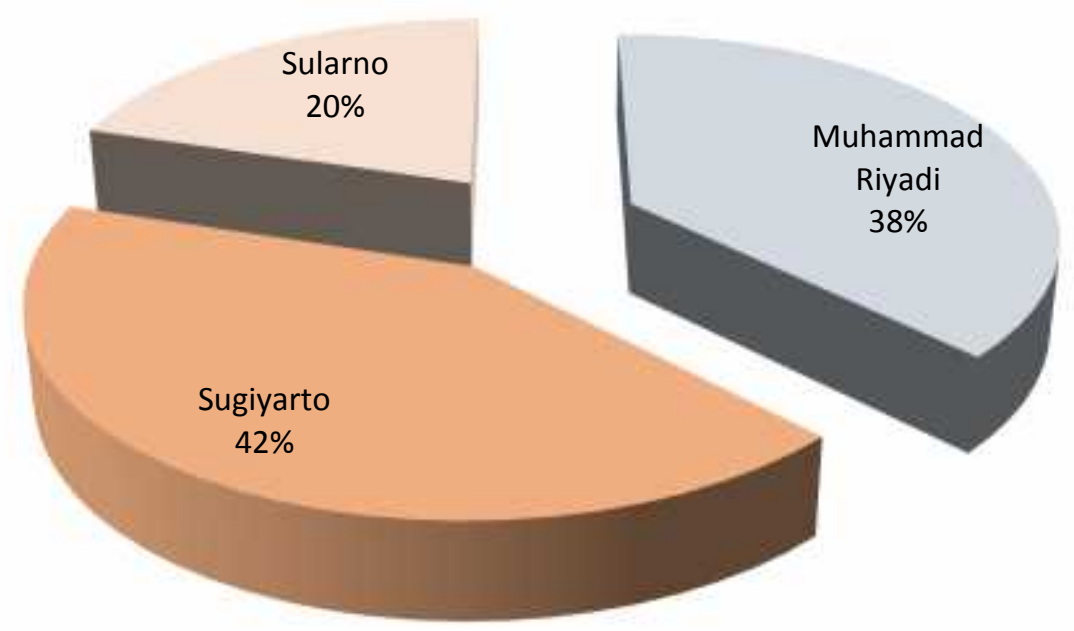

Grafik 4.3.

Perolehan Suara Calon Kepala Desa pada Kelompok Penyelengara Pemungutan Suara (KPPS) Pemilihan Kepala Desa Gebyog Tahun 2020

Berdasarkan hasil perolehan suara pada pemungutan suara pemilihan kepala desa Gebyog Tahun 2020 calon kepala desa dengan nomor urut 2 Sdr. Sugiyarto memperoleh suara terbanyak sejumlah 1780 suara. Sesuai dengan peraturan bahwa Calon Kepala Desa yang memperoleh suara terbanyak dari jumlah suara sah maka Panitia Pemilihan Kepala Desa Gebyog tahun 2020 menetapkan Sdr. Sugiyarto sebagai calon Kepala Desa terpilih.

\section{Penetapan Calon Kepala Desa}

Penetapan Kepala Desa terpilih diatur pada pasal 44 Permendagri 112 tahun 2014 tentang Pemilihan Kepala Desa. Panitia pemilihan kepala desa menyampaikan laporan hasil pemilihan kepala desa kepada BPD. BPD berdasarkan laporan hasil pemilihan kepala desa menyampaikan calon kepala desa terpilih berdasarkan suara terbanyak kepada Bupati/Walikota melalui camat dengan tembusan kepada kepala desa. Bupati/Walikota menetapkan pengesahan dan pengangkatan kepala desa dengan keputusan Bupati/Walikota. 
Pelantikan kepala desa hasil pemilihan kepala desa di Kabupaten Karanganyar Tahun 2020 dilaksanakan pada tanggal 03 April 2020 bertempat di Ruang Anturium Rumdin Bupati Karanganyar.

\section{Faktor Pendukung Dan Penghambat Pelaksanaan Pemilihan Kepala Desa}

1. Faktor Pendukung Pemilihan Kepala Desa

a. Partisipasi masyarakat dalam kegiatan kampanye calon kepala desa Calon kepala desa mengkampanyekan program kerjanya kepada masyarakat yang pelaksanaannya diatur oleh panitia pemilihan. Kampanye adalah suatu kegiatan yang dilakukan oleh Calon Kepala Desa untuk meyakinkan para pemilih dalam rangka mendapatkan dukungan. Setiap calon kepala desa mempunyai cara masing-masing guna menarik perhatian masyarakat.

Partisipasi warga Gebyog terhadap kampanye calon kepala desa sangat luar biasa. Masing-masing calon kepala desa mengadakan konvoi sepeda motor dan mobil yang ikut dalam kegiatan kampanye calon kepala desa. Peserta juga memakai kaos seragam yang dibagi oleh para calon kepala desa.

b. Keikutsertaan dalam pemungutan suara

Partisipasi warga masyarakat dalam pemungutan suara pemilihan kepala desa dilihat dari jumlah yang hadir pada pemungutan suara 4.243 orang dari jumlah Daftar Pemilih Tetap (DPT) 5.046 atau $84,09 \%$. Jumlah yang tidak hadir dalam pemungutan suara 803 orang atau $15,9 \%$. Ketidakhadiran ini dikarenakan sebagai berikut:

1) warga bekerja di luar kota / luar negeri yang tidak dapat pulang karena pekerjaan

2) Orang tua jompo dan sakit

3) Masyarakat yang karena sesuatu mengambil sikap tidak ikut memilih dalam pemungutan suara.

\section{Faktor Penghambat dalam pemilihan kepala desa}

a. Tingkat pendidikan

Tingkat pendidikan masyarakat mempengaruhi budaya politik seseorang. Sebagai contoh masyarakat dengan tingkat pendidikan cukup dan tinggi akan memiliki partisipasi politik yang lebih tinggi ketimbang masyarakat dengan tingkat pendidikan yang rendah. Karena tanpa pendidikan budaya politik tidak akan berkembang. Dalam pemilihan kepala desa budaya komunitarian sangat kuat di masyarakat sehingga partisipasi politik terikat oleh rasa kekeluargaan dan motivasi masyarakat dalam memilih bukan karena rasionalitas, sehingga tingkat pendidikan tidak mempengaruhi partisipasi dalam pemilihan. 
b. Sosialisasi tata cara dan prosedur pemilihan

Kurangnya sosialisasi terhadap tata cara dan prosedur pemilihan mempunyai pengaruh terhadap antusias masyarakat dalam pemungutan suara. Panitia Pemilihan Kepala Desa Tingkat Desa sudah mengumumkan kepada masyarakat dan sosialisasi tahapantahapan pemilihan kepala desa karena kurangnya pemahamanan terhadap prosedur pemilihan masyarakat tidak melakukan cek daftar pemilih pada Daftar Pemilih Sementara (DPS) sampai batas waktu penentuan Daftar Pemilih Tetap. Sehingga pada waktu panitia pemilihan membagikan undangan pemungutan suara warga ada yang tidak dapat kartu undangan ternyata dicek dalam Daftar Pemilih Tetap namanya tidak tercantum.

\section{SIMPULAN}

1. Pelaksanaan pemilihan kepala desa di Desa Gebyog Tahun 2020 dimulai dari tahapan persiapan, pencalonan hingga pemungutan suara dapat penulis simpulkan bahwa telah berjalan sesuai dengan prosedur.

2. Faktor penghambat pelaksanaan pemilihan kepala desa Gebyog tahun 2020 yaitu tingkat pendidikan, dan kurangnya pemahaman terhadap aturan pemilihan kepala desa yang berlaku. Faktor pendukung pelaksanaan pemilihan kepala desa Gebyog Tahun 2020 yaitu Partisipasi masyarakat dalam kegiatan kampanye calon kepala desa dan tingginya tingkat partisipasi masyarakat dalam pemungutan suara pemilihan kepala desa. 
CIVICS EDUCATION AND SOCIAL SCIENSE JOURNAL(CESSJ)

Volume 2 Nomor 2 Edisi Bulan Desember 2020

\section{REFERENSI}

Arikunto, Suharsimi. 2006. Prosedur Penelitian Suatu Pendekatan Praktik (edisi Revisi VI), Jakarta: Rineka Cipta.

https://grobogan.go.id/info/artikel/558-pilkades-dan-pembelajaran-politik https://id.wikipedia.org/wiki/Kepala_desa diakses 20 Maret 2020 pukul 19.00 https://pastiguna.com/teknik-analisis-data https://yogifajarpebrian13.wordpress.com/2011/04/12/pengertian-negara-hukum/

Juniarso Ridwan, Achmad Sodik Sudrajat, 2009, Hukum Administrasi Negara Dan Kebijakan Pelayanan Publik, Bandung: Nuansa, hal 75.

Moleong, Lexy. 2006. Metode Penelitian Kualitatif. Bandung : PT. Remaja Rosdakarya

Mona, 2015, Undang-undang Republik Indonesia Nomor 6 Tahun 2014 tentang Desa dan Peraturan Pelaksanaannya, Yogyakarta: penerbit Pustaka Mahardika.

Nazir. Moh. 2011.MetodePenelitian.GhaliaIndonesia.Bogor.Halm.174

Nuryanto. Iwan. 2013. Partisipasi Masyarakat Dalam Pilkades Tahun 2013 (Penelitian di Desa Batursari, Kecamatan Mranggen, Kabupaten Demak). Skripsi. FISIP. Ilmu Pemerintahan. Universitas Diponegoro. Semarang.

Peraturan Menteri Dalam Negeri Republik Indonesia Nomor 84 Tahun 2015 tentang Susunan Organisasi dan Tata Kerja Pemerintah Desa

Peraturan Pemerintah Nomor 72 tahun 2005 tentang Desa

Rostina. 2016. Analisis Penyelenggaraan Pemilihan Kepala Desa Serentak Di Desa Benteng Tellue Kecamatan Amali Kabupaten Bone Tahun 2015. Skripsi. Program Studi Ilmu Pemerintah. FISIP. Universitas H Hasanudin Makasar

Sartono Sahlan dan Awaludin Marwan. 2012. Nasib Demokrasi Lokal di negeri Barbar. Thafa Media.

Subagyo. Joko. 2011. Metode Penelitian: Dalam Teori dan Praktek. Rineka Cipta .Jakarta. Halm. 86

JORNAL PROGDI PPKn, FKIP UNIVET BANTARA SUKOHARJO BEKERJA SAMA DENGANASSOSIASI PROFESI PENDIDIKAN PANCASILA DAN KEWARGANEGARAAN (AP3KNI) JAWA TENGAH 
CIVICS EDUCATION AND SOCIAL SCIENSE JOURNAL(CESSJ)

Volume 2 Nomor 2 Edisi Bulan Desember 2020

Sugiyono, 2010. Metode Penelitian Kualitatif Kuantitatif, Bandung: Alfabeta

Sugiyono, 2014. Metode penelitian pendekatan kuantitatif, kualitatif dan $R \& D$. Bandung : Alfabeta

Sutopo. H.B. 2002. Metodologi Penelitian Kualitatif Dasar Teori dan Terapannya dalam Penelitian. Surakarta : UNS Press.

Undang-undang nomor 22 tahun 1999 tentang desa

Undang-undang Nomor 32 Tahun 2004 tentang Pemerintahan Desa.

Yogyakarta.Halm.92 